\title{
Effects of proline on copper transport in rice seedlings under excess copper stress
}

\author{
Chien-Teh Chen ${ }^{\text {a }}$, Tsai-Huei Chen ${ }^{\text {b }}$, Kuo-Fu Lo ${ }^{\text {a }}$, Chih-Yu Chiu ${ }^{\mathrm{a}, *}$ \\ a Institute of Botany, Academia Sinica, Taipei 11529, Taiwan, ROC \\ b Taiwan Forestry Research Institute, Taipei, Taiwan, ROC
}

Received 29 May 2003; received in revised form 18 August 2003; accepted 20 August 2003

\begin{abstract}
Copper exposure affects water flux and ion path in rice seedlings. To characterize the factors related to $\mathrm{Cu}$ transport in response to $\mathrm{Cu}$ exposure, rice (Oryza sativa cv. Taichung Native 1) seedlings grown by hyperculture were subjected to excess $\mathrm{CuSO}_{4}$ treatments, and $\mathrm{Cu}$ transport, water flux (transpiration rate and xylem sap extrusion), and proline level were assessed. Excess Cu decreased the water flux of rice seedlings. In spite of the decrease in water flux, $\mathrm{Cu}$ upward transport increased steadily with time. The absorption of $\mathrm{Cu}$ in roots displayed a phase lag between 3 and $12 \mathrm{~h}$ of $\mathrm{Cu}$ exposure, while proline content in the rice roots decreased dramatically. The supplement of proline in culture medium increased water flux and $\mathrm{Cu}$ upward transport in mild $\mathrm{Cu}$-treated rice seedlings. In extreme $\mathrm{Cu}$ treatment, however, proline supplement decreased $\mathrm{Cu}$ upward transport, as the extent of water flux raised by proline supplement was diminished. Proline supplement to $\mathrm{Cu}$-treated rice seedlings not only reduced the $\mathrm{Cu}$ absorption in the roots but also the $\mathrm{Cu}$ exclusion, suggesting supplement of proline accompanied by $\mathrm{Cu}$ exposure induce a barrier of $\mathrm{Cu}$ influx and efflux in rice roots. Therefore, it was concluded that excess $\mathrm{Cu}$ leads to inadequate proline and results in the malfunction of copper transport barrier in rice roots.
\end{abstract}

(C) 2003 Elsevier Ireland Ltd. All rights reserved.

Keywords: Copper stress; Proline; Rice root; Transport; Water flux

\section{Introduction}

Phytoremediation, defined as the use of plants to extract pollutants from the contaminated environment $[1,2]$, is being considered as a promising technology for the recovery of soils contaminated with heavy metals. The accomplishment of the soil recovery through phytoremdiation relies on several factors, including the extent of soil contamination, metal availability for uptake into roots, and plant ability to seize, absorb, and accumulate metals in their shoots [3]. Salt et al. [4] reported that wind boost metal flux to the shoots, while application of abscisic acid that block transpiration also reduce metal accumulation in the shoots. Thus, it implies that one strategy for increasing the efficiency of phytoextraction is to increase the metal translocation to the shoot by increasing plant transpiration. However, plant water transport was

\footnotetext{
* Corresponding author. Tel.: +886-2-27899590x410; fax: $+886-2-27827954$.

E-mail address: bochiu@sinica.edu.tw (C.-Y. Chiu).
}

often blocked by heavy metal stress and resulted in limiting transport of metals [5].

Proline accumulation is a widespread phenomenon among plants under water deficiency and has often been associated with osmoregulation [6]. Thus, it is reasonable to link the metabolism of proline and heavy metals stress in plants. In fact, many species, such as wheat [7], Lemma minor [8], Silene vulgaris [9], rice [10], have been found to accumulate proline in response to $\mathrm{Cu}$ exposure. However, most of the studies were focused on the shoots and not much attention has been paid on the roots. Besides, the studies on the root proline metabolism in response to heavy meals were ambiguous. Saradhi and Saradhi [11] detected the proline accumulation in the roots of Cajanus cajan, Vigna mungo, and Triticum aestivum as exposed to cadmium, cobalt, zinc, and lead. Chen and Kao [12] found $\mathrm{Cd}$ exposure increased the proline content in rice roots. However, Bassi and Sharma [7] observed a fluctuating pattern of proline accumulation in wheat roots in response to $\mathrm{Zn}$ and $\mathrm{Cu}$ exposure. Thomas et al. [13] reported that $\mathrm{Cu}$ exposure decreased the proline content in the roots of Mesembryanthemum crystallinum. 
Thus, the causes and the effects of proline metabolism in roots were remained to be elucidated.

Our previous studies showed $\mathrm{Cu}$ exposure induced proline accumulation in the detached leaves of rice seedlings [10]. Proline accumulation is also induced by $\mathrm{Cd}$ exposure in the roots of etiolated rice seedlings [12]. Thus, the present studies were aimed to test the assumption that $\mathrm{Cu}$ exposure might induce proline accumulation in the roots of rice seedlings. However, in the present report, we found that $\mathrm{Cu}$ exposure decreased proline contents in rice roots. Therefore, in order to understand the possible roles of proline reduction in rice roots, exogenous supply of proline in the rice culture medium was processed and the transport of water and $\mathrm{Cu}$ in rice seedlings were monitored.

\section{Materials and methods}

\subsection{Plant material}

The rice (Oryza sativa cv. Taichung Native 1) seedlings were grown as modified from Ref. [10] and were cultured on a stainless steel net floating on half-strength Johnson's modified nutrient solution ( $\mathrm{pH} 4.8)$ in a 11 plastic vessel. The nutrient solution was renewed every 3 days. The seedlings were grown for 10 days in a controlled room, where it had $300 \mu \mathrm{M}$ photons $\mathrm{m}^{-2} \mathrm{~s}^{-1}$ on the top of the canopy supplied by fluorescent/incandescent lamps with $14 \mathrm{~h}$ light period. Relative humidity was controlled to about $50 \%$ with a vaporizer. Temperature was maintained between 25 and $30^{\circ} \mathrm{C}$. The preparation of etiolated rice seedlings exactly followed the procedure in Ref. [12].

\subsection{Copper exposure and proline supplement}

Twenty rice seedlings with third leaf fully expanded were selected and transferred to a $100 \mathrm{ml}$ beaker containing $40 \mathrm{ml}$ of nutrient for 1 day recovery, then the new nutrient $(40 \mathrm{ml})$ with various concentrations of $\mathrm{CuSO}_{4}$ and L-proline were added to begin the treatment. After the treatment, seedlings were washed with $100 \mathrm{ml}$ distilled water for three times, then were separated to shoots and roots by scissors and discarded the seeds. Finally, the plant tissues were quickly fixed in liquid nitrogen and stored in a $-20^{\circ} \mathrm{C}$ freezer before analysis.

\subsection{Cell wall preparation}

The cell walls were prepared by homogenizing plant materials in cold phosphate buffer $(50 \mathrm{mM}, \mathrm{pH} 5.8)$ using a mortar and pestle. The homogenate was centrifuged at $1000 \times g$ and washed at least four times with $50 \mathrm{mM}$ phosphate buffer [14]. After washing, the supernatants were collected for determining the free $\mathrm{Cu}$ content, and the pellets were used for determining the cell wall bounded $\mathrm{Cu}$ content.

\subsection{Determination of $\mathrm{Cu}, \mathrm{K}$, proline, and} malondialdehyde (MDA)

For the determination of $\mathrm{Cu}$ and $\mathrm{K}$, plant materials were placed in a digested bottle, and $10 \mathrm{ml} 70 \% \mathrm{HNO}_{3}$ solution predigested under a hood for $20 \mathrm{~min}$ were added. With the lids covered, the samples were placed in a microwave oven (Chem Co, Mars-5) for 10 min [15]. The clear sample solutions then were filtered with Whatman \#42 filter paper, and diluted to $25 \mathrm{ml}$ in a volumetric flask. Copper and potassium concentrations in plant tissues were determined by Inductively Coupled Plasma-Atomic Emission Spectrometry (model: JY124), Jobin-Yvon, France. Proline was extracted and its concentration was determined by the method of Bates et al. [16]. Plant tissues were homogenized with 3\% sulfosalicylic acid and the homogenates were centrifuged at $3000 \times g$ for $20 \mathrm{~min}$. The supernatant was treated with acetic acid and ninhydrin, boiled for $1 \mathrm{~h}$, and then the absorbance at $520 \mathrm{~nm}$ was determined. MDA, routinely used as an indicator of lipid peroxidation, was extracted with $5 \%(w / v)$ trichloroacetic acid and determined according to Ref. [17], where the level of lipid peroxidation products in the samples was expressed as 2-thiobarbituric acid reactive materials (aldehydes, mainly MDA and endoeroxides) [18].

\subsection{Determination of relative water content, transpiration rate, and xylem sap extrusion rate}

Relative water content, defined as the water content of leaf tissue as a percentage that of the fully turgid tissue, was determined according to the Ref. [19]. Twenty rice shoots were soaked in distilled water for $8 \mathrm{~h}$, weighted to get the turgid weight, and then the plant shoots were dried in a $70^{\circ} \mathrm{C}$ oven to get the dry weight. The relative water content is defined as: (fresh weight - dry weight) / (turgid weight - dry weight) $\times$ $100 \%$.

Transpiration rates were calculated as the amount of nutrient in the beaker lost within $2 \mathrm{~h}$. Beakers containing $40 \mathrm{ml}$ of nutrient without plant were used as the blank. Xylem sap extrusion rates were calculated as the amount of xylem sap collected from 10 cutting stalks of rice seedlings. Within $1 \mathrm{~h}$ and in every $10 \mathrm{~min}$ after cutting, xylem saps were collected using a filter paper of $1 \mathrm{~cm} \times 4 \mathrm{~cm}$. The weight in weight of filter paper at final collection was counted as the amount of xylem sap extrusion.

\subsection{Determination of $\mathrm{Cu}$ exclusion}

Rice seedlings that treated with $0.5 \mathrm{mM}$ of $\mathrm{CuSO}_{4}$ for $8 \mathrm{~h}$ were washed with distilled water for three times, and then transferred to the nutrients with or without proline for $12 \mathrm{~h}$ in the light. After that, the amount of $\mathrm{Cu}$ in nutrients was counted as the rate of $\mathrm{Cu}$ exclusion in rice roots.

\subsection{Data analysis}

All the treatments in each experiment had three replicates or more. Every experiment was repeated at least two times, 
and one was selected for the graphical representation. Comparison of two means was performed using the Student's $t$-test with $P=0.05$. Comparison of multiple means was performed using the Duncan's multiple range test with $P=$ 0.05 .

\section{Results}

\subsection{Copper absorption and transport}

Rice seedlings exposed to excess $\mathrm{Cu}$ in the nutrient solution accumulated substantial amounts of $\mathrm{Cu}$ in their roots and shoots (Fig. 1). Approximately $95 \%$ of the $\mathrm{Cu}$ absorbed in rice seedlings was found in the roots (Table 1), where $40 \%$ of $\mathrm{Cu}$ absorbed was retained in the cell wall and $60 \%$ were in free form. Only $5 \%$ of $\mathrm{Cu}$ was found in the shoots, where $12 \%$ of those retained in the cell wall. Potassium contents were reduced in the roots as $\mathrm{Cu}$ concentrations in nutrient was higher than $0.1 \mathrm{mM}$, but potassium contents in the shoots were unaffected in all ranges of $\mathrm{Cu}$ treatment (Fig. 1).

The accumulation of $\mathrm{Cu}$ in rice shoots and roots was monitored during $24 \mathrm{~h}$ of extreme $(0.5 \mathrm{mM}) \mathrm{Cu}$ treatment (Fig. 2). In the shoots, $\mathrm{Cu}$ accumulation appeared at $6 \mathrm{~h}$ of $\mathrm{Cu}$ exposure and accumulated constantly thereafter. In the roots, $\mathrm{Cu}$ content accumulated rapidly within $3 \mathrm{~h}$ of exposure, then a phase lag occurred from 3 to $12 \mathrm{~h}$, and, subsequently, a rapid accumulation occurred after $12 \mathrm{~h}$.
Table 1

Distribution of $\mathrm{Cu}$ content in rice shoots and roots

\begin{tabular}{lll}
\hline & $\begin{array}{l}\text { Shoot } \\
\left(\mu \mathrm{mol} \mathrm{g}^{-1} \mathrm{DW}\right)\end{array}$ & $\begin{array}{l}\text { Root } \\
\left(\mu \mathrm{mol} \mathrm{g}^{-1} \mathrm{DW}\right)\end{array}$ \\
\hline Free form & $0.96 \pm 0.18$ & $11.96 \pm 0.86$ \\
Cell wall bounded & $0.13 \pm 0.05$ & $7.98 \pm 0.59$ \\
Total & 1.09 & 19.94
\end{tabular}

\subsection{Water flux and root growth}

While $\mathrm{Cu}$ accumulated constantly in rice shoots upon extreme $\mathrm{Cu}$ treatment (Fig. 2), the rates of water transpiration and xylem sap extrusion in rice seedlings declined within $3 \mathrm{~h}$ (Fig. 3). Thereafter, the relative water content of shoot decreased after $12 \mathrm{~h}$ of treatment. The cease of root growth was significant at $24 \mathrm{~h}$.

\subsection{Proline content and lipid peroxidation}

The $\mathrm{Cu}$ exposure increased proline content and lipid peroxidation in rice shoots, but both were decreased in the rice roots (Fig. 4). During $24 \mathrm{~h}$ of $0.5 \mathrm{mM} \mathrm{Cu}$ treatment (Fig. 5), the proline levels increased in the shoots within $6 \mathrm{~h}$ of $\mathrm{Cu}$ exposure, whereas it decreased gradually in the roots. Most of proline aggregated was observed in the rice root tips (Fig. 6), but copper exposure decreased proline contents in the root tips.
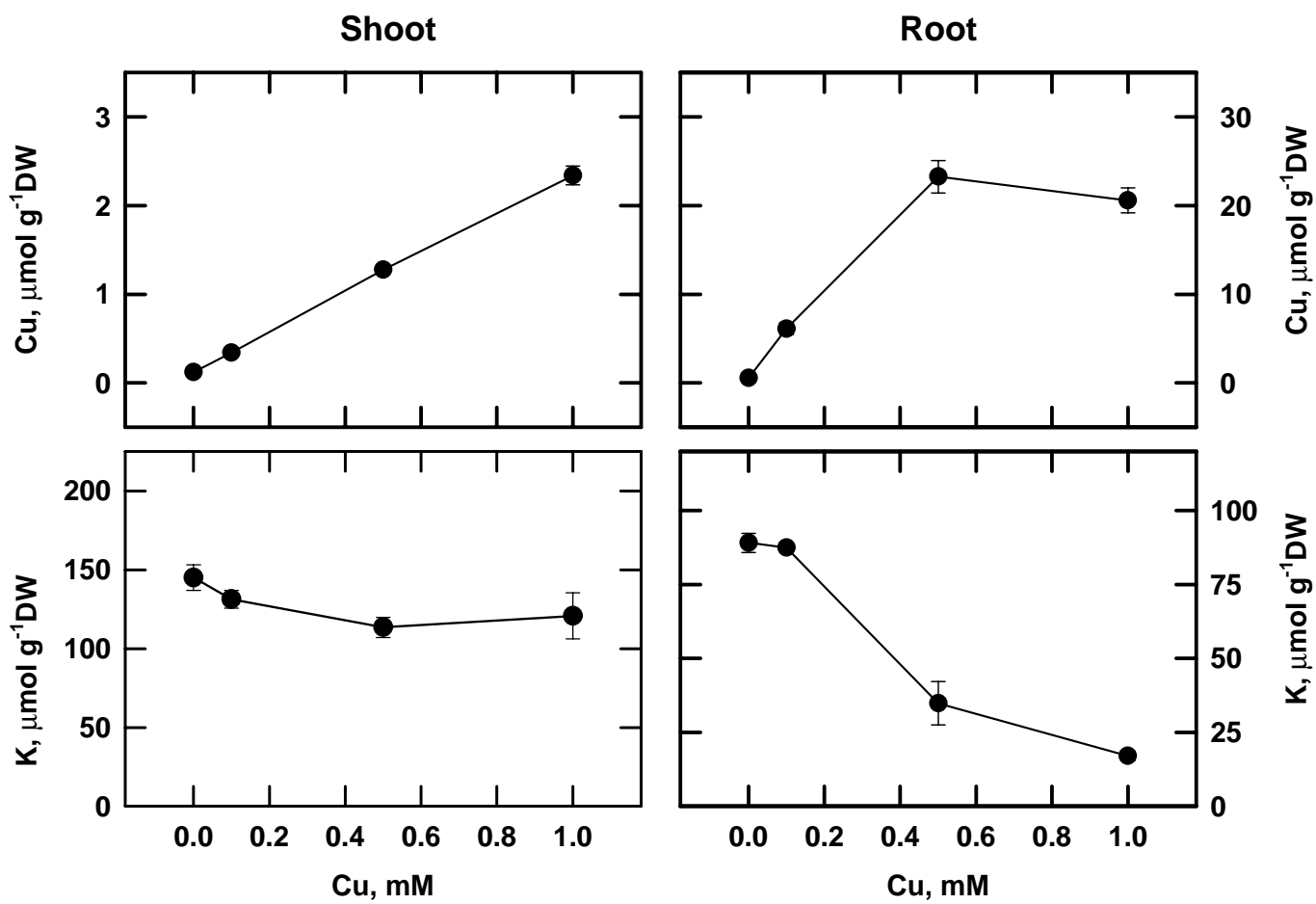

Fig. 1. Effect of $\mathrm{CuSO}_{4}$ on copper and potassium contents in rice shoots and roots. Rice seedlings were treated with various concentrations of CuSO 4 for $24 \mathrm{~h}$ in the light. Vertical bars represent standard errors $(n=3)$. 


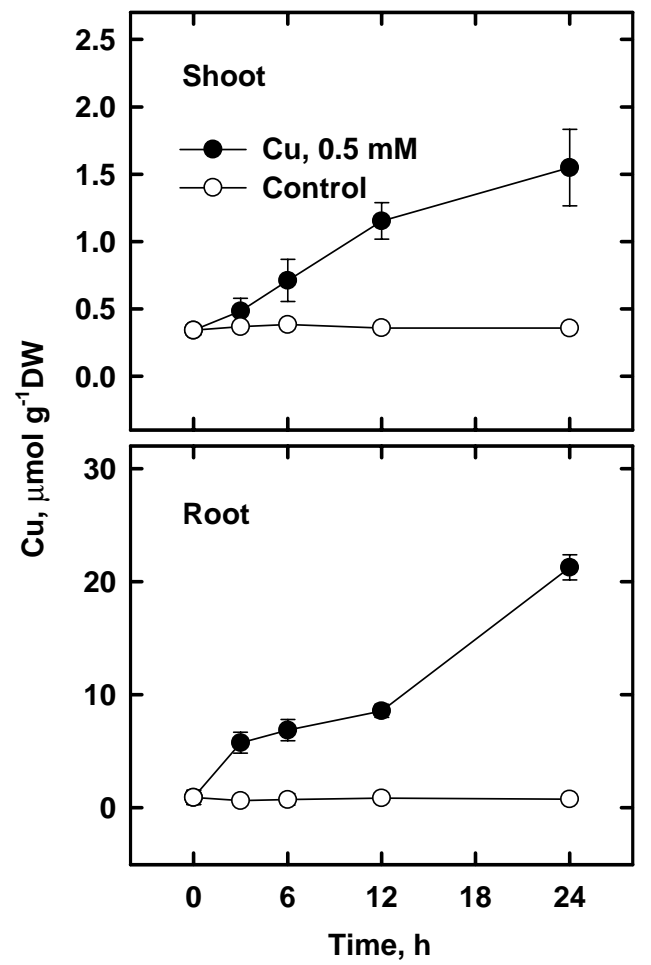

Fig. 2. Time course of the $\mathrm{CuSO}_{4}$ effect on copper contents in rice shoots and roots. Rice seedlings were treated with $0.5 \mathrm{mM}$ of $\mathrm{CuSO}_{4}$ in the light. Vertical bars represent standard errors $(n=3)$.

\subsection{Proline supplement}

The $\mathrm{Cu}$ exposure decreased water transpiration rate in rice seedlings, but the supplement of proline in the nutrient retarded the decrease of transpiration rate (Fig. 7). Meanwhile, the $\mathrm{Cu}$ contents in rice shoots were increased by proline supplement with mild $\mathrm{Cu}$ treatment $(0.05$ and $0.1 \mathrm{mM})$. However, at extreme $\mathrm{Cu}$ treatment $(0.5 \mathrm{mM})$, the $\mathrm{Cu}$ content in the shoots was decreased by proline supplement. In the roots, proline supplement decreased the $\mathrm{Cu}$ content as nutrient $\mathrm{Cu}$ was higher than $0.05 \mathrm{mM}$. Potassium content was decreased only in the case of $0.5 \mathrm{mM} \mathrm{Cu}$ exposure, while proline supplement restrained the decrease. In mild $\mathrm{Cu}(0.1 \mathrm{mM})$ exposure, the extrusion rate of xylem sap decreased, the proline supplement restored the extrusion rate as the same as the control (Fig. 8). The supplement of proline alone increased the extrusion rate of xylem sap in rice seedlings. In Fig. 9, the supplement of proline on Cu-treated rice seedlings decreased the exclusion of $\mathrm{Cu}$ from rice roots into culture medium.

\section{Discussion}

The lifting of heavy metals from roots to shoots is of great concern to those who are interested in phytoremediation. Many reports showed that most $\mathrm{Cu}$ taken up was retained in

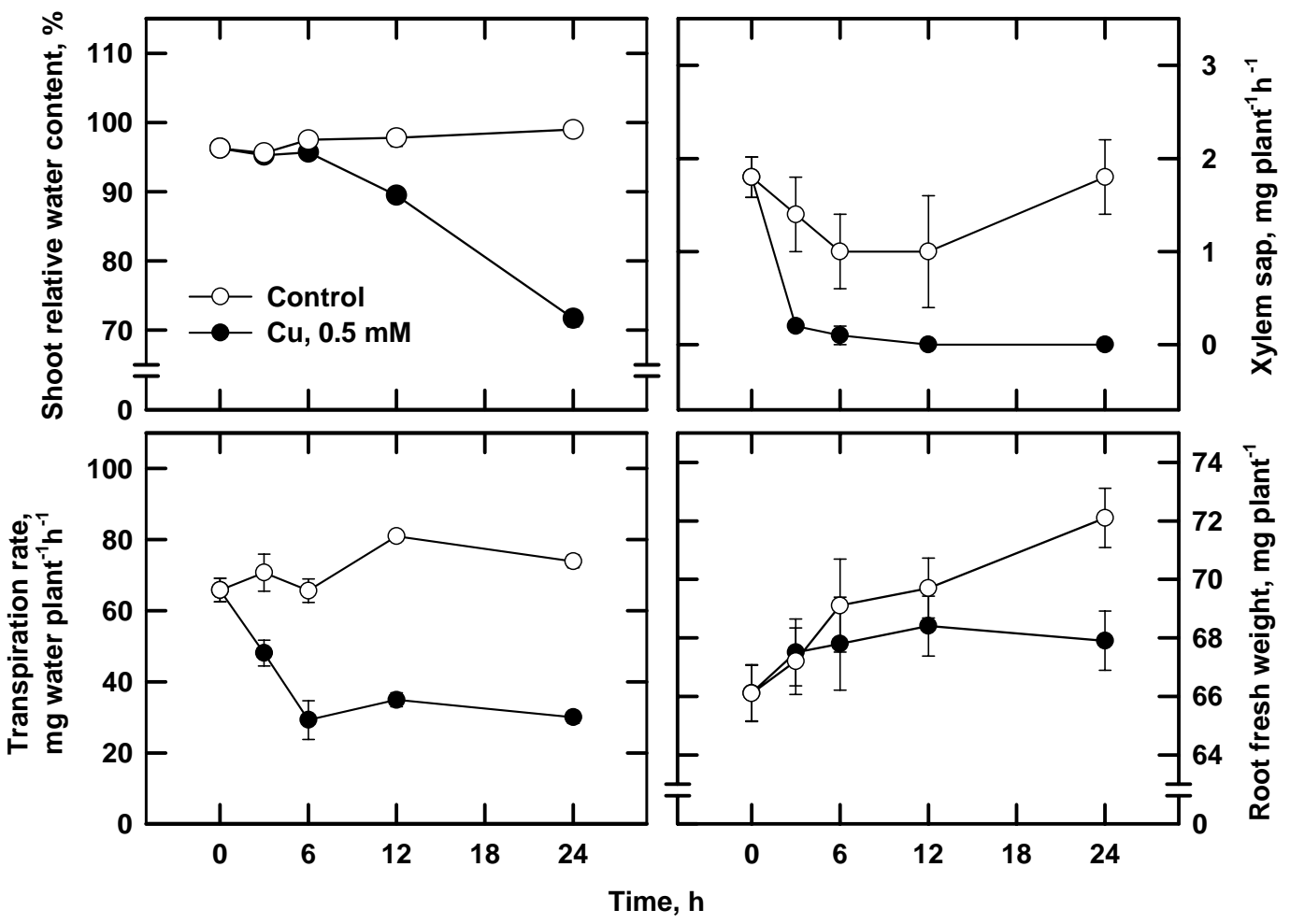

Fig. 3. Time course of the $\mathrm{CuSO}_{4}$ effect on relative water content, transpiration rate, xylem sap, and root fresh weight in rice seedlings. Rice seedlings were treated with $0.5 \mathrm{mM}$ of $\mathrm{CuSO}_{4}$ in the light. Vertical bars represent standard errors $(n=4)$. 
Shoot
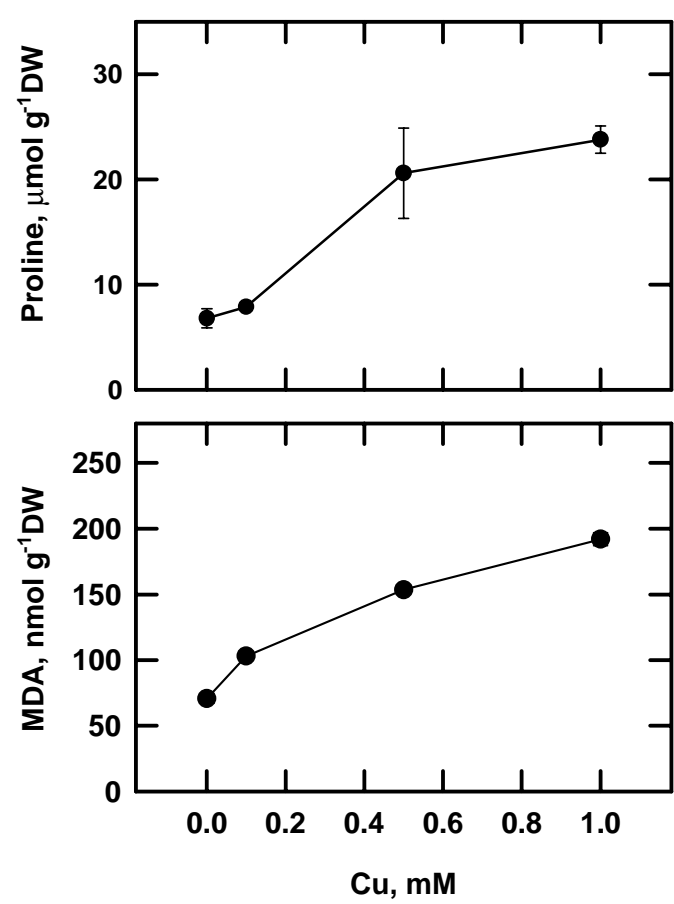

Root
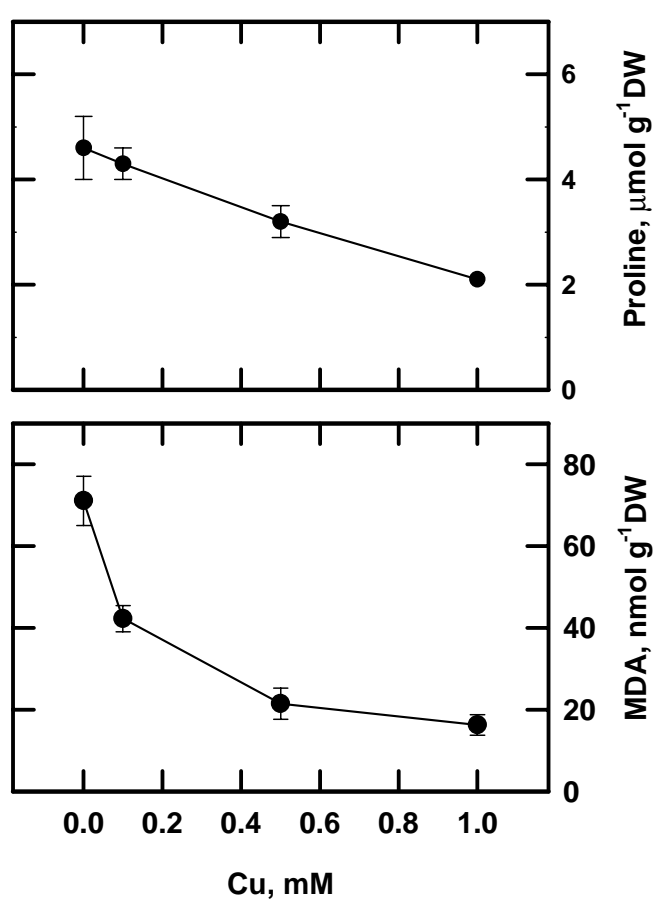

Fig. 4. Effect of $\mathrm{CuSO}_{4}$ on proline and malondialdehyde (MDA) in rice shoots and roots. Rice seedlings were treated with various concentrations of $\mathrm{CuSO}_{4}$ for $24 \mathrm{~h}$ in the light. Vertical bars represent standard errors $(n=3)$.

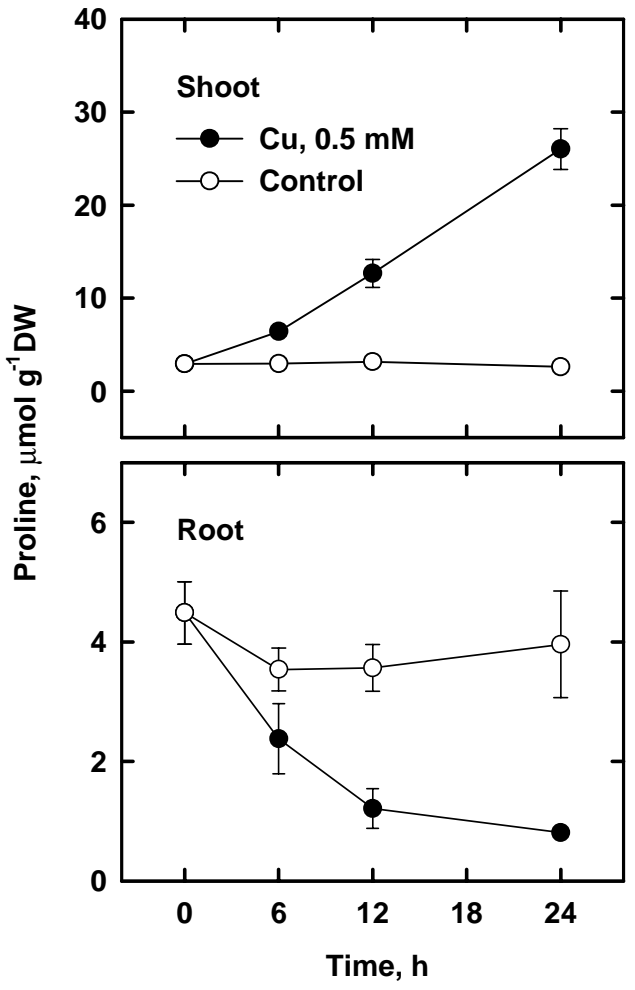

Fig. 5. Time course of the $\mathrm{CuSO}_{4}$ effect on proline contents in rice shoots and roots. Rice seedlings were treated with $0.5 \mathrm{mM}$ of $\mathrm{CuSO}_{4}$ in the light. Vertical bars represent standard errors $(n=3)$. the roots [20-22]. Liao et al. [23] suggested that the withholding of $\mathrm{Cu}$ by roots restricted the $\mathrm{Cu}$ translocation to xylem and shoots. Our results agree with the above findings and observed around $95 \%$ of the $\mathrm{Cu}$ taken up retained in the rice roots (Fig. 1). It is worth noting that about $40 \%$ of $\mathrm{Cu}$ in the root tissue was immobilized in the cell wall (Table 1). Even though, the remaining $60 \%$ of $\mathrm{Cu}$ taken up were not fully available for transport, only $5 \%$ of the Cu taken up was transported to the shoots. The explanations could be chelated by peptides [24], compartmented into vacuole [25] or simply blocked by endodermis [26]. The unusual amino acid nicotianamine (NA) was suggested to be essential for heavy metals transport in the phloem [27]. Furthermore, it has been also observed that in tomato plants, NA stimulate copper transport in the xylem [28]. Therefore, the restricted translocation of $\mathrm{Cu}$ in rice root might be due to the inadequate amount of NA.

Substantial evidences suggested that the translocation of heavy metals was driven mainly by water flux due to transpiration and root pressure [4,29-31]. In spite of the decrease in transpiration rate and root pressure (xylem sap extrusion rate) under $\mathrm{Cu}$ exposure (Fig. 3), the amount of $\mathrm{Cu}$ in the rice shoots increased constantly (Fig. 2), suggesting that the path of xylem could be substituted by another path. Hence, xylem was not the only path for $\mathrm{Cu}$ upward transport in rice seedlings. Similar results were also obtained by Thornton and Macklon [32]; they found that water flux only had a little effect on the uptake of $\mathrm{Cu}$ in ryegrass seedlings. In 


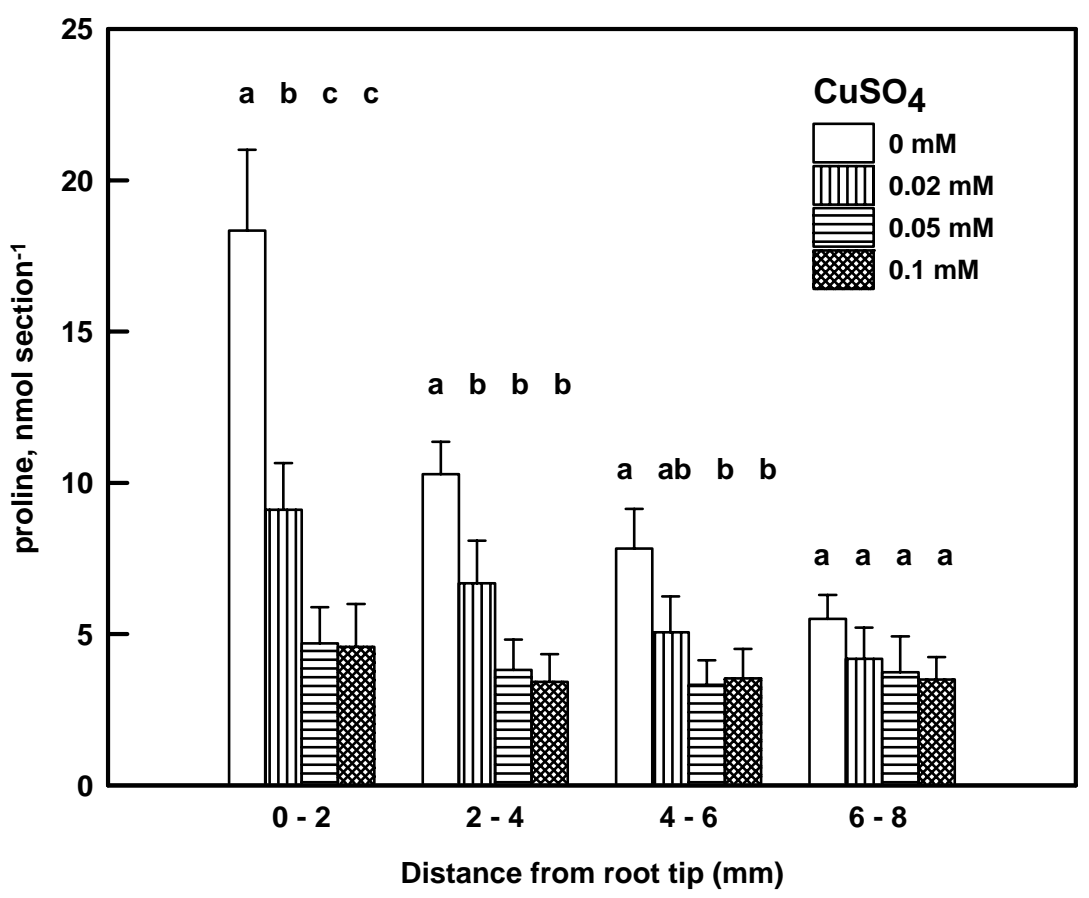

Fig. 6. Effect of $\mathrm{CuSO}_{4}$ on the distribution of proline in rice roots. Three days old etiolated rice seedlings were treated with various concentrations of $\mathrm{CuSO}_{4}$ for 5 days in the dark. The sections of root tissue were cut from the root tip by every 2 mm. Each section contains the segments of 10 roots. Vertical bars represent standard errors $(n=6)$. Means labeled with different letters differ significantly $(P=0.05)$.

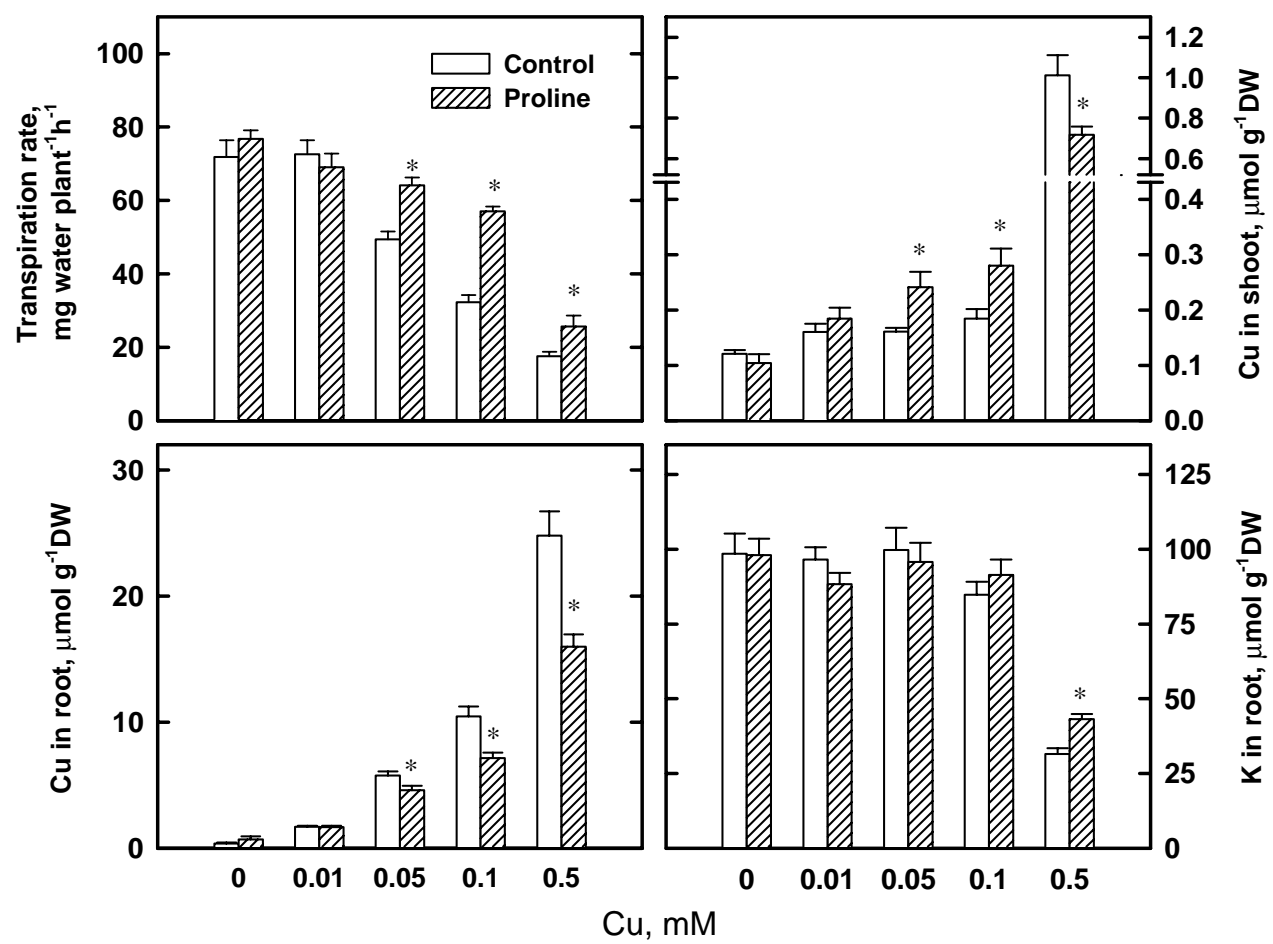

Fig. 7. Effect of proline supplement on transpiration rate, copper and potassium contents in rice seedlings exposed to copper. Rice seedlings were treated with $1 \mathrm{mM}$ L-proline plus various concentrations of $\mathrm{CuSO}_{4}$ for $24 \mathrm{~h}$ in the light. Vertical bars represent standard errors $(n=3)$. Means labeled with asterisk $(*)$ differ significantly $(P=0.05)$. 


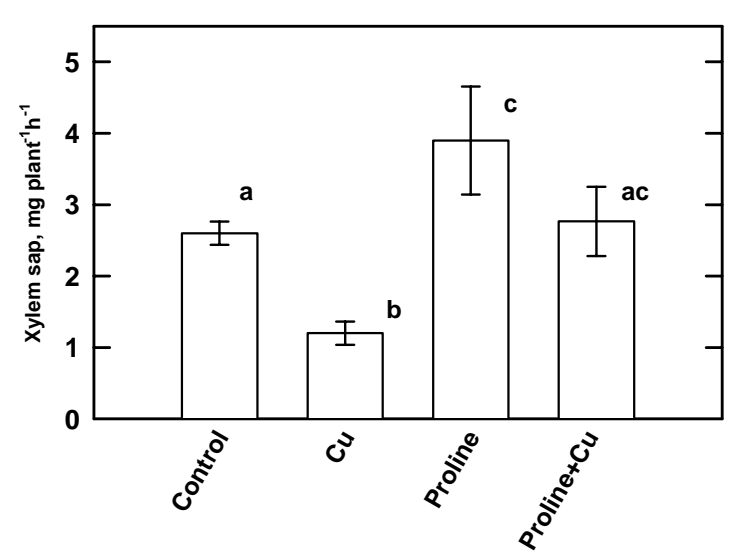

Fig. 8. Effect of proline supplement on xylem sap extrusion in rice seedlings exposed to copper. Rice seedlings were treated with (or without) $1 \mathrm{mM}$ L-proline and with (or without) $0.1 \mathrm{mM}$ of $\mathrm{CuSO}_{4}$ for $24 \mathrm{~h}$ in the light. Vertical bars represent standard errors $(n=4)$. Means labeled with different letters differ significantly $(P=0.05)$.

addition, numerous reports suggested that the transport of $\mathrm{Cu}$ and other metal ions via the path of phloem [33-35].

Proline is known to accumulate under heavy metal exposure and considered to involve in stress resistance [36,37]. Our previous studies showed that $\mathrm{Cu}$ was effective in inducing proline accumulation in the detached rice leaves [10]. To our surprise, the proline metabolism of rice seedlings in response to $\mathrm{Cu}$ exposure was different between shoots and roots (Figs. 4 and 5). Cu exposure increased the proline content and the degree of lipid peroxidation in rice shoots, but decreased in the rice roots. It was also observed that the responses of rice roots to $\mathrm{Cu}$ exposure were different from that of $\mathrm{Cd}$ exposure [12], where $\mathrm{Cd}$ increased the rice root proline content. Since the material used in the $\mathrm{Cd}$ experiment were etiolated rice seedlings, the experiment of $\mathrm{Cu}$ exposure on etiolated rice seedlings with the same growth condition as in $\mathrm{Cd}$ experiment was processed. The outcome showed that the root proline content was decreased in etio-

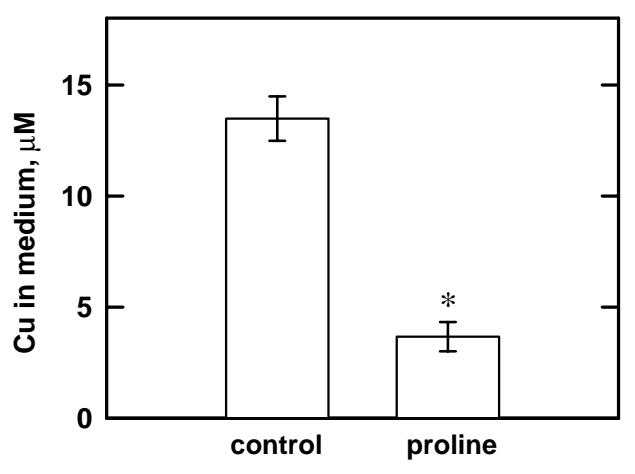

Fig. 9. Effect of proline supplement on copper exclusion in rice seedlings exposed to copper. Rice seedlings were pretreated with $0.5 \mathrm{mM}$ of $\mathrm{CuSO}_{4}$ for $8 \mathrm{~h}$ in the light, then transferred to the nutrients with or without $1 \mathrm{mM}$ of L-proline for $12 \mathrm{~h}$. Amounts of $\mathrm{Cu}$ in nutrients were counted as the copper exclusion ability in rice roots. Vertical bars represent standard errors $(n=3)$. Means labeled with asterisk $(*)$ differ significantly $(P=0.05)$. lated rice seedlings as exposed in excess $\mathrm{Cu}$ (Fig. 6), suggesting the existence of specificity among heavy metals to rice seedlings. Proline was found to relocate and accumulate in maize root tip during water stress treatment [38,39]. It is suspected that the proline content in the root tips could be raised by way of proline relocation even the total content of proline in rice root is decline. The result in Fig. 6 did not find the relocation of proline and, thus, excluded that suspicion.

The possible roles of proline in rice roots under $\mathrm{Cu}$ exposure were illustrated in the experiment of proline supplement (Fig. 7). In the mild $\mathrm{Cu}(0.05-0.1 \mathrm{mM})$ exposure, proline supplement increased the transport of $\mathrm{Cu}$ to shoots accompanied by the increases in water flux (transpiration and root pressure) (Figs. 7 and 8), suggesting that the increase in water flux increases $\mathrm{Cu}$ transport by way of xylem upon mild $\mathrm{Cu}$ exposure. Thus, the task of xylem on $\mathrm{Cu}$ upward transport cannot be excluded through it could be substituted by another path.

Proline has long been recognized as the protector against the stress environment $[36,37,40]$. The result in Fig. 8 showed the root pressure was maintained by proline supplement. It thus suggested that proline supplement under mild $\mathrm{Cu}$ exposure can prevent the root tissue from damage by $\mathrm{Cu}$ toxicity. Since proline supplement reduced the $\mathrm{Cu}$ content in the roots under mild $\mathrm{Cu}$ exposure (Fig. 7), it is plausible that proline supplement alleviates the burden of rice roots from mild $\mathrm{Cu}$ exposure through the enhancement of $\mathrm{Cu}$ upward transport. Furthermore, since the amounts of $\mathrm{Cu}$ reduced in the roots far beyond the amounts upward transport to shoots, proline supplement alleviates the burden may also through the reduction of $\mathrm{Cu}$ inward entry from nutrient.

When the amount of $\mathrm{Cu}$ in nutrient solution reached the extreme range $(>0.5 \mathrm{mM})$, the supplement of proline, however, does not increase the $\mathrm{Cu}$ upward transport. In contrast, the amount of $\mathrm{Cu}$ in the rice shoots was reduced by proline supplement. In the meantime, the extent of water flow raised by proline supplement was diminished; suggesting proline supplement does not enhance the upward transport of $\mathrm{Cu}$, but still can reduce the entry of $\mathrm{Cu}$. Since the transpiration rates of rice seedlings under extreme $\mathrm{Cu}$ exposure were reduced enormously in contrast to the increasing amounts of $\mathrm{Cu}$ in the shoots, it was likely that, under extreme $\mathrm{Cu}$ exposure, the $\mathrm{Cu}$ transport mainly through the path of phloem and driven by the concentration gradient of $\mathrm{Cu}$ in the roots [41]. Hence, as the proline supplement reduced the $\mathrm{Cu}$ contents in the roots, the upward transport of $\mathrm{Cu}$ was reduced.

The supplement of proline reduced $\mathrm{Cu}$ contents in both mild and extreme $\mathrm{Cu}$-treated rice roots. This was unlikely due to the increase of $\mathrm{Cu}$ transport to shoots, because the amount of $\mathrm{Cu}$ increased in the shoots could not compensate the amount of $\mathrm{Cu}$ decreased in roots. The studies in Chlorella cells by Wu et al. [42] showed that exogenous supply of proline to Chlorella cell culture medium after $\mathrm{Cu}$ treatment resulted in massive exclusion of absorbed $\mathrm{Cu}$, hence the uptake of $\mathrm{Cu}$ in Chlorella cells was reduced. However, the present study in rice roots yielded contradictory results 
(Fig. 9). The present study showed that the exclusion of $\mathrm{Cu}$ in rice roots was reduced by proline supplement. Thus, the less accumulation of $\mathrm{Cu}$ in rice roots resulted from proline supplement was unlikely due to the increase of $\mathrm{Cu}$ exclusion. Therefore, proline supplement in rice roots decreases not only $\mathrm{Cu}$ exclusion but also its uptake, suggesting that proline supplement on $\mathrm{Cu}$-treated rice roots induced a barrier, by which the efflux and influx of $\mathrm{Cu}$ in rice roots were blocked.

Lignin was reported to form a hydrophobic matrix as it penetrates into cell wall, by which a barrier was created to obstruct the access of hydrophilic compounds [43]. Proline-rich (PRPs) and hydroxyproline-rich (HRGPs) glycoproteins are coupled with lignin deposition and likely function as foci for lignin polymerization [43]. The studies in antisense transgenic Arabidopsis thaliana indicated that proline deficiency in transgenic specifically affected the synthesis of PRPs and HRGPs [40]. It is likely that the deficiency of proline in rice roots resulted from $\mathrm{Cu}$ exposure might affect the synthesis of PRPs and HRGPs and led to the defect of cell wall lignification. In addition, the supplement of proline was able to overcome the shortage of proline in rice roots and probably gave enough resource for the synthesis of PRPs and HRGPs in rice roots under $\mathrm{Cu}$ exposure, by which the $\mathrm{Cu}$ influx decreased in the roots. In fact, a phase lag of $\mathrm{Cu}$ absorption occurred between 3 and $12 \mathrm{~h}$ of $\mathrm{Cu}$ exposure in accordance with the decline of proline content (supposed to be used for the synthesis of PRPs and HRGPs) (Fig. 2). Thereafter, as to the extent of proline deficiency and limiting lignin deposition, the absorption of $\mathrm{Cu}$ in rice roots increased dramatically after $12 \mathrm{~h}$ of $\mathrm{Cu}$ exposure.

Copper was reported to increase cell permeability, probably due to membrane damage, where rapid leakage of $\mathrm{K}$ has been widely interpreted as a symptom of $\mathrm{Cu}$-induced oxidative damage to the plasma membrane [44-46]. In fact, a decrease of $\mathrm{K}$ content in rice roots in response to extreme $\mathrm{Cu}$ exposure is observed in Figs. 2 and 7. Copper is known to damage cell membranes by inducing lipid peroxidation $[36,44]$. Estimation of MDA is the most widely used method for the indication of oxidative stress, but Cherif et al. [47] reported that MDA cannot be related to lipid peroxidation in habituated sugarbeet plant cells due to the interferon-like pigments, sugars, and polyamines. Our results in Fig. 4 showed that MDA decreased in response to $\mathrm{Cu}$ exposure, perhaps due to the interferon like their reports. However, the existence of oxidative stress in rice roots induced by $\mathrm{Cu}$ exposure cannot be ruled out because several antioxidative enzyme activities and $\mathrm{H}_{2} \mathrm{O}_{2}$ levels have been found to increase in rice roots by $\mathrm{Cu}$ exposure [14].

In summary, $\mathrm{Cu}$ exposure decreased the water flux (transpiration rate and xylem sap extrusion) of rice seedlings. However, water flux was not the solo driving force for $\mathrm{Cu}$ translocation in rice seedlings. Proline content in the rice roots was decreased remarkably by $\mathrm{Cu}$ exposure. Proline supplement increased the $\mathrm{Cu}$ upward transport in mild
$\mathrm{Cu}$-treated rice seedlings, but decreased the $\mathrm{Cu}$ transport in extreme $\mathrm{Cu}$ treatment. Proline supplement reduced the $\mathrm{Cu}$ absorption and exclusion in the roots of $\mathrm{Cu}$-treated rice seedlings, indicating excess $\mathrm{Cu}$ leads to the inadequate of proline and results in the malfunction of copper transport barrier in rice roots.

\section{References}

[1] I. Raskin, P.B.A.N. Kumar, S. Dushenkov, D.E. Salt, Bioconcentration of heavy metals by plants, Curr. Opin. Biotechnol. 5 (1994) 285-290.

[2] S.D. Cunningham, W.R. Berti, J.W. Huang, Phytoremediation of contaminated soils, Trends Biotechnol. 13 (1995) 393-397.

[3] D.E. Salt, R.D. Smith, I. Raskin, Phytoremedition, Annu. Rev. Plant Physiol. Mol. Biol. 49 (1998) 643-668.

[4] D.E. Salt, R.C. Prince, I.J. Pickering, I. Raskin, Mechanisms of cadmium mobility and accumulation in India Mustard, Plant Physiol. 109 (1995) 1427-1433.

[5] J. Barcelo, C. Poschenrieder, Plant water relations as affected by heavy metal stress: a review, J. Plant Nutr. 13 (1990) 1-37.

[6] S. Henda, A.K. Handa, P.M. Hasegawa, R.A. Bessan, Proline accumulation and the adaptation of cultured plant cells to water stress, Plant Physiol. 80 (1986) 938-945.

[7] R. Bassi, S.S. Sharma, Proline accumulation in wheat seedlings exposed to zinc and copper, Phytochemistry 33 (1993) 1339-1342.

[8] R. Bassi, S.S. Sharma, Changes in proline content accompanying the uptake of zinc and copper by Lemna minor, Ann. Bot. 72 (1993) 151-154.

[9] H. Schat, S.S. Sharma, R. Vooijs, Heavy metal-induced accumulation of free proline in a metal-tolerant and a nontolerant ecotype of Silene vulgaris, Physiol. Plant. 101 (1997) 477-482.

[10] C.T. Chen, L.M. Chen, C.L. Lin, C.H. Kao, Regulation of proline accumulation in detached rice leaves exposed to excess copper, Plant Sci. 160 (2001) 283-290.

[11] A. Saradhi, P.P. Saradhi, Proline accumulation under metal stress, J. Plant Physiol. 183 (1991) 554-558.

[12] S.L. Chen, C.H. Kao, Cd induced changes in proline level and peroxidase activity in roots of rice seedlings, Plant Growth Regul. 17 (1995) 67-71.

[13] J.C. Thomas, F.K. Malick, C. Endreszl, E.C. Davies, K.S. Murray, Distinct responses to copper stress in the halophyte Mesembryanthemum crystallinum, Physiol. Plant. 102 (1998) 360-368.

[14] L.M. Chen, C.L. Lin, C.H. Kao, Copper toxicity in rice seedlings: changes in antioxidative enzyme activities, $\mathrm{H}_{2} \mathrm{O}_{2}$ level, and cell wall peroxidase activity in roots, Bot. Bull. Acad. Sin. 41 (2000) 99-103.

[15] G.S.R. Krishnamurti, P.M. Huang, K.C.J. Van Ress, L.M. Kozak, H.P.W. Rostad, Microwave digestion for detection of total cadmium in soils, Soil Sci. Plant Anal. 25 (1994) 615-625.

[16] L.S. Bates, R.P. Waldren, I.D. Teare, Rapid determination of free proline for water stress studies, Plant Soil 39 (1973) 205-207.

[17] R.L. Heath, L. Packer, Photoperoxidation in isolated chloroplasts. I. Kinetics and stoichiometry of fatty acid peroxidation, Arch. Biochem. Biophys. 25 (1968) 189-198.

[18] J.A. Buege, S.D. Aust, Microsomal lipid peroxidation, Methods Enzymol. 52 (1978) 302-310.

[19] P.F. Weatherly, Studies in the water relation of cotton plant. I. The field measurement of water deficits in the leaves, New Phytol. 49 (1950) 81-97.

[20] S.O. Borgegard, H. Rydin, Biomass, root penetration and heavy metal uptake in birch, in a soil cover over copper tailings, J. Appl. Ecol. 26 (1989) 585-595.

[21] T. Punshon, N.W. Lepp, N.M. Dickinson, Resistance to copper toxicity in some British Willows, J. Geochem. Explor. 52 (1995) 259-266. 
[22] I. Arduini, D.L. Godbold, A. Onnis, Cadmium and copper uptake and distribution in Mediterranean tree seedlings, Physiol. Plant. 97 (1996) 111-117.

[23] M.T. Liao, M.J. Hedley, D.J. Woolley, R.R. Brooks, M.A. Nichols, Copper uptake and translocation in chiory (Cichorium intybus L. cv. Grasslands Puna) and tomato (Lycopersicon esculentum Mill. cv. Rondy) plants grown in NFT system. I. Copper uptake and distribution in plants, Plant Soil 221 (2000) 135-142.

[24] W.E. Rauser, Phytochelatins and related peptides, Plant Physiol. 109 (1995) 1141-1149.

[25] U. Kramer, I.J. Pickering, I. Raskin, D.E. Salt, Subcellular localization and speculation of nickel in hyperaccumulator and nonaccumulator Thlaspi species, Plant Physiol. 122 (2000) 1343-1353.

[26] M. Wierzbicka, Lead accumulation and its translocation barriers in roots of Allinm cepa $\mathrm{L}$-autoradiographic and ultrastructural studies, Plant Cell Environ. 10 (1987) 17-26.

[27] U.W. Stephan, G. Scholz, Nicotianamine: mediator of transport of iron and heavy metals in the phloem? Physiol. Plant. 88 (1993) 522-529.

[28] A. Pich, G. Scholz, Translocation of copper and other micronutrients in tomato plants (Lycopersicon esculentum Mill.): nicotianamine-stimulated copper transport in the xylem, J. Exp. Bot. 47 (1996) 41-47.

[29] S.C. Jarvis, D.C. Whitehead, The absorption distribution and concentration of copper in white clover grown on a range of soils, Plant Soil 75 (1983) 427-434.

[30] H. Marschner, Mineral Nutrition of Higher Plants, 2nd ed., Academic Press, London, 1993, pp. 79-115.

[31] A. Haag-Kerwer, H.J. Schafer, S. Heiss, C. Walter, T. Rausch, Cadmium exposure in Brassica juncea causes a decline in transpiration rate and leaf expansion without effect on phytosynthesis, J. Exp. Bot. 50 (1999) 1827-1835.

[32] B. Thornton, A.E.S. Macklon, Copper uptake by ryegrass seedlings; contribution of cell wall adsorption, J. Exp. Bot. 40 (1989) 11051111.

[33] P.J. Hocking, The composition of phloem exudates and xylem sap from tree tobacco (Nicotiana glauca Grah.), Ann. Bot. 45 (1980) 633-643.

[34] J.S. Pate, Transport and partitioning of nitrogenous solutes, Ann. Rev. Plant Physiol. 31 (1980) 313-340.

[35] I. Schmidke, U.W. Stephan, Transport of metal micronutrients in the phloem of castor bean (Ricinus communis) seedlings, Physiol. Plant. 95 (1995) 147-153.
[36] C. De Vos, M. Ten Bookum, R. Vooijs, H. Schat, L. De Kok, Effect of copper on fatty acid composition and peroxidation of lipids in the roots of copper tolerant and sensitive Silene cucubalus, Plant Physiol. Biochem. 31 (1993) 151-158.

[37] P.B.K. Kishor, Z. Hong, G.H. Miao, C.A.A. Hu, D.P.S. Verma, Overexpression of $\left[\Delta^{1}\right]$-pyrroline-5-carboxylate synthetase increases proline production and confers osmotolerance in transgenic plants, Plant Physiol. 108 (1995) 1387-1394.

[38] E.S. Ober, R.E. Sharp, Proline accumulation in maize (Zea mays L.) primary roots at low water potentials. I. Requirement for increased levels of abscisic acid, Plant Physiol. 105 (1994) 981-987.

[39] P.E. Verslues, R.E. Sharp, Proline accumulation in maize (Zea mays L.) primary roots at low water potentials. II. Metabolic source of increased proline deposition in the elongation zone, Plant Physiol. 119 (1999) 1349-1360.

[40] T. Nanjo, M. Kobayashi, Y. Yoshiba, Y. Sanada, K. Wada, H. Tsukaya, Y. Kakuburi, K. Yamaguchi-Shinozaki, K. Shinozaki, Biological functions of proline in morphogenesis and osmotolerance revealed in antisense transgenic Arabidopsis thaliana, Plant J. 18 (1999) 185-193.

[41] D.B. Fisher, Long-distance transport, in: B. Buchanan, W. Gruissem, R. Jones (Eds.), Biochemistry and Molecular Biology of Plants, American Society of Plant Physiologists, Rockville, MD, 2000, pp. 730-783.

[42] J.T. Wu, M.T. Hsieh, L.C. Know, Role of proline accumulation in response to toxic copper in Chlorella sp. (Chlorophyceae) cells, J. Phycol. 34 (1998) 113-117.

[43] K. Iiyama, T.B. Lam, B.A. Stone, Covalent cross-links in the cell wall, Plant Physiol. 104 (1994) 315-320.

[44] C. De Vos, H. Schat, R. Vooijs, W. Ernst, Copper induced damage to the permeability barriers in roots of Silene cucubalus, J. Plant Physiol. 135 (1989) 164-165.

[45] C. De Vos, H. Schat H, M. De Waal, R. Vooijs, W. Ernst, Increased resistance to copper induced damage of the root cell plasmalemma in copper tolerant Silene cucubalus, Physiol. Plant. 82 (1991) 523528.

[46] A.S. Murphy, W.R. Eisinger, J.E. Shaff, L.V. Kochian, L. Taiz, Early copper-induced leakage of $\mathrm{K}^{+}$from Arabidopsis seedlings is mediated by ion channels and coupled to citrate efflux, Plant Physiol. 121 (1999) 1375-1382.

[47] M. Cherif, P. Nodet, D. Hagege, Malondialdehyde cannot be related to lipoperoxidation in habituated sugarbeet plant cells, Phytochemistry 41 (1996) 1523-1526. 